\title{
Quantification of vital adherent Streptococcus sanguinis cells on protein-coated titanium after disinfectant treatment
}

\author{
Monika Astasov-Frauenhoffer • Olivier Braissant • \\ Irmgard Hauser-Gerspach • A. U. Daniels • \\ Dieter Wirz • Roland Weiger • Tuomas Waltimo
}

Received: 7 April 2011/Accepted: 6 June 2011/Published online: 14 June 2011

(C) Springer Science+Business Media, LLC 2011

\begin{abstract}
The quantification of vital adherent bacteria is challenging, especially when efficacy of antimicrobial agents is to be evaluated. In this study three different methods were compared in order to quantify vital adherent Streptococcus sanguinis cells after exposure to disinfectants. An anaerobic flow chamber model accomplished initial adhesion of S. sanguinis on protein-coated titanium. Effects of chlorhexidine, Betadine ${ }^{\circledR}$, Octenidol ${ }^{\circledR}$, and ProntOral $^{\circledR}$ were assessed by quantifying vital cells using Live/Dead BacLight ${ }^{\mathrm{TM}}$, conventional culturing and isothermal microcalorimetry (IMC). Results were analysed by Kruskal-Wallis one-way analysis of variance. Live/dead staining revealed highest vital cell counts $(P<0.05)$ and demonstrated dose-dependent effect for all disinfectants. Microcalorimetry showed time-delayed heat flow peaks that were proportioned to the remaining number of viable cells. Over $48 \mathrm{~h}$ there was no difference in total heat between treated and untreated samples $(P>0.05)$, indicating equivalent numbers of bacteria were created and disinfectants delayed growth but did not eliminate it. In conclusion, contrary to culturing, live/dead staining
\end{abstract}

M. Astasov-Frauenhoffer $(\bowtie) \cdot$ I. Hauser-Gerspach .

T. Waltimo

Institute of Preventive Dentistry and Oral Microbiology,

School of Dental Medicine, University of Basel,

Hebelstrasse 3, 4056 Basel, Switzerland

e-mail: m.astasov-frauenhoffer@unibas.ch

O. Braissant · A. U. Daniels · D. Wirz

Laboratory of Biomechanics and Biocalorimetry,

c/o Biozentrum/Pharmazentrum, University of Basel,

Klingelbergstrasse 50-70, 4056 Basel, Switzerland

R. Weiger

Clinic for Periodontology, Endodontology and Cariology,

University of Basel, Hebelstrasse 3, 4056 Basel, Switzerland enables detection of cells that may be viable but non-cultivable. Microcalorimetry allows unique evaluation of relative disinfectant effects by quantifying differences in time delay of regrowth of remaining vital cells.

\section{Introduction}

Reliable quantification of vital adherent microorganisms on surfaces of various biomaterials is challenging. Fluorescence microscopy and conventional culturing methods have commonly been applied for the quantification of vital bacteria after direct exposure to disinfectants [1-9].

Determination of vital and dead bacterial cells by fluorescence microscopy is based on the intactness of the cell membrane. The fluorescence agent Syto 9 labels all the cells, whereas propidium iodide attaches only on cells with damaged membranes. Intact and damaged cells appear green and red when exposed to wavelengths of $450-490$ and $546 \mathrm{~nm}$, respectively [10]. This practical technique has been widely used in assessment of the vitality status of planktonic and adherent microorganisms [1-10]. Due to the three-dimensional nature of wellestablished biofilms such Syto 9/propidium iodide-based fluorescence microscopy has commonly been combined with confocal laser scanning microscopy. This enables observations also in the deeper layers of the biofilm $[4,6$, $11,12]$. Determination of the vitality of adherent microorganisms by conventional culturing requires their resuspension prior to cultivation and subsequent quantification of colony-forming units. Several factors-such as physical damage to the cells by resuspension or lack of growth due to suboptimal culture conditions-may cause the culture method to yield partially false negative results. Consequently, using both fluorescent microscopy and 
conventional culture methods commonly give results which are not always in accord [13]. This may also be due to viable but non-cultivable (VBNC) microorganisms [14]. Despite their typically low levels of metabolic activity, bacteria may switch again to being cultivable when the culture conditions improve, a process called resuscitation [15].

Isothermal microcalorimetry (IMC) has become a promising tool for monitoring heat flow generated by various (micro)biological metabolic activities in vitro. Modern microcalorimeters are very sensitive and can measure heat production rates of less than a microwattequivalent to the combined metabolic output of a few hundred thousand active bacteria [16]. Thus, metabolism and growth of relatively limited numbers of bacteria can be monitored continuously and accurately at any chosen temperature [17-19]. In microbiology, microcalorimetry has been used to determine replication rates of bacterial cells [20, 21], effects of biocides on microbial activity [22, 23], and bacterial coaggregation [24] as well as to identificy bacterial species by the patterns of their heat flow rate curves [25-28]. Hauser-Gerspach et al. [29] showed that IMC allows estimating the rate of bacterial adhesion onto surfaces. In that study IMC could also differentiate effects of buffer (saline vs. saliva) and material surface area, using different baseline numbers of readily-adherent Streptococcus sanguinis.

Based on its ability to measure growth and also detect bactericidal (and bacteriostatic) effects, IMC could be suitable for the determination of the number of vital adherent bacteria on various surfaces. Integration of the heat flow curves ( $\mu \mathrm{W}=$ vs. $\mu \mathrm{J} / \mathrm{s}$ vs. time) obtained by IMC provides the cumulative amount of heat ( $\mathrm{J}$ vs. time) which is proportional to the cumulative amount of biomass formed. This allows determination of time the bacteria need to reach the exponential growth phase using the growth model of Gompertz [30, 31]. This lag time depends on the bacterial concentration of the sample; therefore defining it as a dependent variable to detect differences between standardized concentrations, provides a mathematical relationship between the time and concentration applicable for any treated sample. Additionally, as IMC allows following the microbial activity of the bacteria over a longer period of time, and thus it can be used to detect whether resuscitation of the VBNC occurs under a given set of conditions.

The aims of this study were to (a) utilize three different methods-live/dead staining, conventional culture method and IMC - to quantify vital adherent $S$. sanguinis cells after direct exposure to disinfectants on protein covered titanium test specimens and (b) determine whether the results were in agreement - or perhaps together provided a more complete picture than any single method.

\section{Materials and methods}

\subsection{Microorganism}

Streptococcus sanguinis (DSM 20068; German Collection of Microorganisms and Tissue Culture Cells, Braunschweig, Germany) was used throughout the study. A $10 \mu \mathrm{l}$ inoculum of $S$. sanguinis in skim milk solution (from $-20^{\circ} \mathrm{C}$ ) was suspended in $5 \mathrm{ml}$ Schaedler broth $\left(\mathrm{BBL}^{\mathrm{TM}}\right.$, Becton-Dickinson, Basel, Switzerland) and incubated at $37^{\circ} \mathrm{C}$ for $8 \mathrm{~h}$. From the 8 -h-old culture a new subculture (1:50) was made, which was grown at $37^{\circ} \mathrm{C}$ for $16 \mathrm{~h}$. Thereafter the culture was ultrasonicated for $30 \mathrm{~s}(30 \mathrm{~W}$; Vibracell, Sonics \& Materials, Newtown, CT); centrifuged at $8500 \mathrm{rpm}$ for $5 \mathrm{~min}$, washed with $0.9 \% \mathrm{NaCl}$ and the cells were harvested again by centrifugation. Bacteria were resuspended in simulated body fluid (SBF) [32] to a density of $10^{8}$ cells $/ \mathrm{ml}$.

\subsection{Saliva and serum}

The saliva was collected (using paraffin chewing stimulation to augment production) from three healthy volunteers according to a recently reported procedure [33]. Briefly, the collected saliva was ultrasonicated for $30 \mathrm{~s}(30 \mathrm{~W}$; Vibracell, Sonics \& Materials, Newtown, CT), filtered through a $70 \mu \mathrm{m}$ filter (Cell Strainer, Becton-Dickinson, Basel, Switzerland) and centrifuged at $22,000 \times g$ for $40 \mathrm{~min}$ at $4^{\circ} \mathrm{C}$. The supernatant was filtered through two connected filters $(0.45$ and $0.22 \mu \mathrm{m}$; Millex-HV and Millex-GV, respectively; Millipore, Switzerland) and frozen at $-20^{\circ} \mathrm{C}$ in aliquots of $10 \mathrm{ml}$ corresponding the need for each individual experiment.

Serum used was a pool from five persons (Blutspendezentrum SRK, Basel, Switzerland). The $\mathrm{pH}$ of the serum/ saliva mixture was adjusted to 7.2 by adding potassium and sodium phosphate buffers $(0.067 \mathrm{~mol} / \mathrm{l})$.

\subsection{Substrate for adhesion}

Polished titanium disks (mean roughness of $120 \mathrm{~nm}$ ), $5 \mathrm{~mm}$ diameter and $1 \mathrm{~mm}$ thick (commercial pure titanium grade 2, ASTM F-67, Straumann AG, Waldenburg, Switzerland) sterilized by steam autoclaving and gamma irradiation were used as substrates for $S$. sanguinis adherence. The sterile disks were exposed for $15 \mathrm{~min}$ to freshly mixed serum/saliva (1:10) solution prior to each experiment in order produce protein pellicle formation [33].

\subsection{Anaerobic flow chamber model}

The flow chamber model has recently been described in detail [33]. Briefly, the system is comprised of a flow 
chamber with the test specimen, a polytetrafluoroethylene dispenser containing the bacterial suspension and a peristaltic pump with an integrated speed controller (flow rate at $0.8 \mathrm{ml} / \mathrm{min}$ ), all the parts are connected by polyvinylchloride tubes. The dispenser and flow chamber are placed on a shaker (260 rev/min) to maintain the homogeneity of the suspension. Circulating bacteria were allowed to adhere on the protein-coated disks under anaerobic conditions (MACS MG, Don Whitley Scientific Ltd; atmosphere of $80 \% \mathrm{~N}_{2}, 10 \% \mathrm{H}_{2}$ and $10 \% \mathrm{CO}_{2}$ ) at $37^{\circ} \mathrm{C}$ for $2 \mathrm{~h}$.

\subsection{Treatment of adherent $S$. sanguinis cells with disinfectants}

Four different disinfectants were used in this study: chlorhexidine (chlorhexidin-D Mundspülung, 0.125\% chlorhexidine digluconate; Universitätsspital Basel, Basel, Switzerland), Betadine ${ }^{\circledR}$ (0.75\% povidone-iodine; Mundipharma, Medical Company, Basel, Switzerland), Octenidol ${ }^{\circledR}$ (0.1\% octenidine; Schülke \& Mayr GmbH, Norderstedt, Germany) and ProntOral ${ }^{\circledR}(0.1-0.25 \%$ polyhexamethylene biguadine; B. Braun Medical AG, Sempach, Switzerland). Each of the four was tested at four different concentrations, which are shown in Table 1. The protein-coated disks with adherent $S$. sanguinis cells were removed from the anaerobic flow chamber after $2 \mathrm{~h}$, dipped gently in sterile saline to remove any non-adherent cells and placed in disinfectant solutions for $30 \mathrm{~s}$. The disk incubated in sterile saline served as a control. After the exposure to the solutions, the disks were gently dipped in sterile saline. The sides and the bottom of the disks were decontaminated with $70 \%$ ethanol for $30 \mathrm{~s}$. Thereafter the specimens were prepared either for live/dead staining and fluorescence microscopy, for culturing by the conventional method or for IMC.

\subsection{Detection of the vitality status of the adherent bacteria}

\subsubsection{Live/dead staining and fuorescence microscopy}

The adherent cells were stained by dual fluorescent dyes (Live/Dead BacLight ${ }^{\mathrm{TM}}$ bacterial Viability Kit; MoBiTec,
Luzern, Switzerland), and analyzed microscopically (x40; Provis AX70, Olympus AG, Volketswil, Switzerland). It has been hypothesized that the use of two fluorescent dyes allows differentiation between vital and dead cells. Syto 9 stains all cells but propidium iodide only stains those with damaged membranes. Microscopic examination using FITC and Cy3 light filters respectively reveals first all cells and then those which are stained by both dyes and are thus "dead". From each disk five randomly selected microscopic fields each of $0.024 \mathrm{~mm}^{2}$ were photographed and the bacteria on the area counted by Analysis program (Olympus AG, Volketswil, Switzerland). All experiments were done three times.

\subsubsection{Conventional culture methods}

The specimens for conventional culture methods were placed in $1 \mathrm{ml} 0.9 \% \mathrm{NaCl}$, vortexed for $1 \mathrm{~min}$ and treated with ultrasound for $15 \mathrm{~s}$ ( $22.5 \mathrm{~W}$; Vibracell, Sonics \& Materials, Newtown, CT) to remove adherent cells from the disks. Serial dilutions were made in sterile saline and aliquots of $0.1 \mathrm{ml}$ were plated on Columbia blood agar plates $\left(\mathrm{BBL}^{\mathrm{TM}}\right.$, Becton-Dickinson, Basel, Switzerland; supplemented with $50 \mathrm{ml} / \mathrm{l}$ of human blood, $0.5 \mathrm{mg} / \mathrm{l}$ of menadione, and $5 \mathrm{mg} / \mathrm{l}$ of hemin) in duplicates and incubated anaerobically at $37^{\circ} \mathrm{C}$ for $48 \mathrm{~h}$. Based on colony morphology and cellular characteristics the purity of the cultures was controlled, colonies were counted and quantified $(\mathrm{CFU} / \mathrm{ml})$. All experiments were done three times.

\subsubsection{Microcalorimetric analysis}

The IMC instrument (TAM 48, TA Instruments, New Castle DE USA) was first set at $37^{\circ} \mathrm{C}$. The titanium disks were then placed in microcalorimetric ampoules filled with $3 \mathrm{ml}$ of Schaedler broth. Each sample was ultrasonicated for $5 \mathrm{~s}(7.5 \mathrm{~W}$; Vibracell). The ampoules were closed under aerobic conditions and each was placed in the equilibration position in one of the 48 chambers of the IMC instrument for $15 \mathrm{~min}$ to allow initial thermal equilibration. After this equilibration phase, the samples were lowered into measuring position and measurement started after $45 \mathrm{~min}$ (i.e., the time required to obtain full thermal

Table 1 Disinfectants and their concentrations used in this study

\begin{tabular}{lllllll}
\hline Product name & Antimicrobial agent & Stock concentration $(\%)$ & \multicolumn{4}{l}{ Used concentrations in this study } \\
\cline { 4 - 6 } & & $1: 1(\%)$ & $1: 2(\%)$ & $1: 4(\%)$ & $1: 8(\%)$ \\
\hline Chlorhexidine & Chlorhexidine digluconate & 0.125 & 0.125 & 0.063 & 0.031 & 0.016 \\
Betadine $^{\circledR}$ & Povidone-iodide & 0.750 & 0.100 & 0.750 & 0.375 & 0.188 \\
Octenidol $^{\circledR}$ & Octenidine HCl & 0.100 & 0.050 & 0.025 & 0.094 \\
ProntOral $^{\circledR}$ & Polyhexamethylene biguanide & $0.100-0.250$ & $0.100-0.250$ & $0.05-0.125$ & $0.025-0.063$ & $0.013-0.031$ \\
\hline
\end{tabular}


equilibration). During all the measurement time, the instrument maintained the set temperature of $37^{\circ} \mathrm{C}$ with an accurracy of $0.02^{\circ} \mathrm{C}$ and a temperature drift less than $2 \mu^{\circ} \mathrm{C}$ and heat flow $(\mu \mathrm{W}=\mu \mathrm{J} / \mathrm{s})$ versus elapsed time was recorded for each ampoule. Calibration of the microcalorimetric experiments was done by determining the lag times of different concentrations of $S$. sanguinis suspension $\left(10^{2}, 5 \times 10^{2}, 10^{3}, 5 \times 10^{3}, 10^{4}, 5 \times 10^{4}, 10^{5} \mathrm{CFU} / \mathrm{ml}\right)$ in $3 \mathrm{ml}$ Schaedler broth (BBL ${ }^{\mathrm{TM}}$, Becton-Dickinson, Basel, Switzerland) in duplicates. The samples were ultrasonicated for $5 \mathrm{~s}$ (7.5 W; Vibracell), closed and placed into the IMC at $37^{\circ} \mathrm{C}$ for analysis. Each experiment was done three times.

For each sample the lag time was calculated by fitting the Gompertz's equation for describing growth curves to the integrated heat-flow curve (i.e. J vs. time) [30, 31]. Curve fitting was performed using the $\mathrm{R}$ software and the "grofit" package. So that heat flow (growth) data for the disinfectant-treated samples could be analyzed, the relationship between the CFU counts and lag time from the calibration assays was determined. The linear regression model was obtained by Stata 10 resulting in equation: $\ln (\mathrm{CFU})=17.972-1.072 *$ lag time(h), with $R^{2}=$ 0.9896. The equation allowed determination of the initial concentration of bacteria in each sample.

Additionally, the maximum growth rate of the bacteria and the accumulated heat over $48 \mathrm{~h}$ were determined using the Gompertz equation as well, in order to see if there were differences in these parameters between disinfectant-treated and untreated control samples.

\subsection{Statistical analysis}

For all three methods the results were evaluated as vitality percentages of the samples. Therefore, the vital cell counts in each of the treated samples were divided by the vital cell counts for untreated control samples and multiplied by 100 . All the results were analyzed by Stata 10 software for the Kruskal-Wallis analysis of variance.

\section{Results}

\subsection{Anaerobic flow chamber}

Bacterial suspension inside the anaerobic flow chamber system maintained the $\mathrm{pH}$ and CFU counts at the same level throughout the $2 \mathrm{~h}$, indicating that the conditions for the bacteria did not change during the experiment. At the beginning and at the end of the experiment the CFU counts per $\mathrm{ml}$ were $6.38 \times 10^{8} \pm 2.18 \times 10^{7}$ and $6.40 \times 10^{8}$ $\pm 1.84 \times 10^{7}$, respectively. The corresponding $\mathrm{pH}$ values ranged from $7.27 \pm 0.05$ and $7.20 \pm 0.06$, respectively.
3.2 Live/dead staining and fluorescence microscopy

Vitality percentages of the adherent cells after the different disinfectant treatments are presented in Fig. 1. The vitality percentage was calculated in relation to the control that was present in each disinfectant group. A dose-dependent effect was observed for chlorhexidine, Betadine ${ }^{\circledR}$ and ProntOral ${ }^{\circledR}$. Octenidol ${ }^{\circledR}$ treatment resulted in a small statistically not significant inconsistency between the 1:8 and 1:4 dilutions, which could be explained by the high efficacy of the disinfectant, resulting overall in a very small percentage of vital cells at both dilutions. Disinfectant treatment resulted in significant differences among the different concentrations of the same disinfectant in all four cases $(P<0.05)$.

Almost no effect on the vitality of the adherent $S$. sanguinis cells was detected by the lowest concentration of chlorhexidine and Betadine ${ }^{\circledR}$. In comparison, Octenidol ${ }^{\circledR}$ and ProntOral ${ }^{\circledR}$ reduced the vitality of the cells far more efficiently at the three lowest concentrations than did chlorhexidine or Betadine ${ }^{\circledR}$. No significant differences were observed among the undiluted original solutions.

\subsection{Conventional culture method}

The results of the colony forming unit (cfu-based) experiments are shown in Fig. 2. (In untreated control samples an average of $2.3 \times 10^{4} \mathrm{CFU} / \mathrm{ml}$ was detected.) A dosedependent effect was observed only with chlorhexidine by this method. Significant differences between the different concentrations of the same disinfectant were present in the chlorhexidine group $(P<0.05)$; the other three disinfectants gave no significant differences for different concentrations. The vitality of the cells was reduced to less than $1 \%$ by the treatment with Betadine ${ }^{\circledR}$, Octenidol ${ }^{\circledR}$ and ProntOral $^{\circledR}$ at all concentrations except 1:8 Octenidol ${ }^{\circledR}$.

A remarkably lower percentage of vital cells were detected by the CFU count experiments than by fluorescent

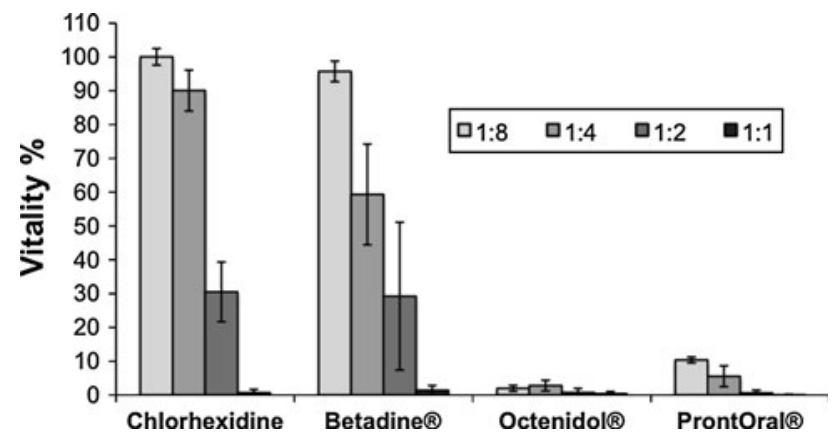

Fig. 1 Vitality percentage of disinfectant-treated samples compared to the untreated control measured by live/dead staining method. As a result mean values with standard deviations are given $(n=3)$ 


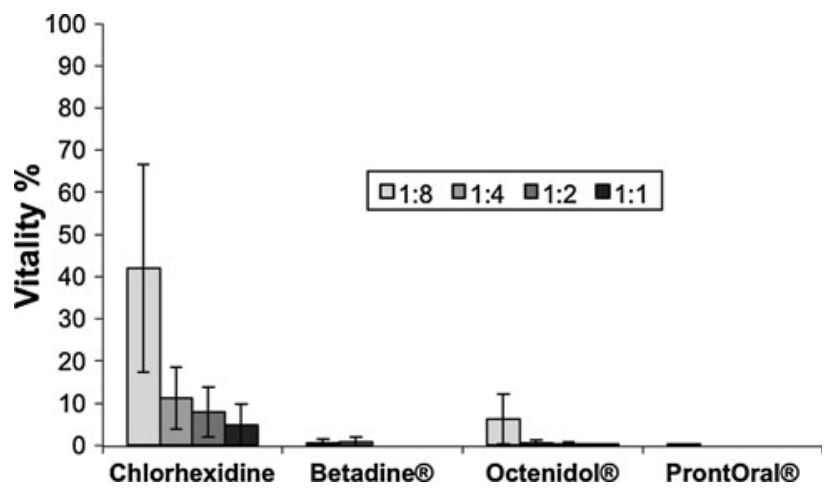

Fig. 2 Vitality percentage of disinfectant-treated samples compared to the untreated control measured by conventional culturing method. Mean values with standard deviations are given $(n=3)$

staining. The biggest difference between the two methods was detected for the treatment with Betadine ${ }^{\circledR}$. The differences in results for the Octenidol ${ }^{\circledR}$ and ProntOral ${ }^{\circledR}$ groups were smaller between the two methods, but still significant at lower concentrations.

\subsection{Isothermal microcalorimetry (IMC)}

The vitality percentages determined by IMC are shown in Fig. 3. (In the untreated control $2.8 \times 10^{4} \mathrm{CFU} / \mathrm{ml}$ were detectable). No dose-dependent effect was observed by this method for reasons explained later. Significant differences among the different concentrations of the same disinfectant were present only in the chlorhexidine group $(P<0.05)$, the other three disinfectants had no significant differences among the results for different concentrations.

The vitality percentages of the cells were lower when determined by IMC compared to either of the other two methods. The highest vitality rate was observed after the treatment with 1:8 dilution of chlorhexidine $(73.32 \% \pm$ 17.24). More than $1 \%$ of vital cells were detected just by four other solutions: $2.74 \% \pm 1.16$ by $1: 4$ of chlorhexidine,

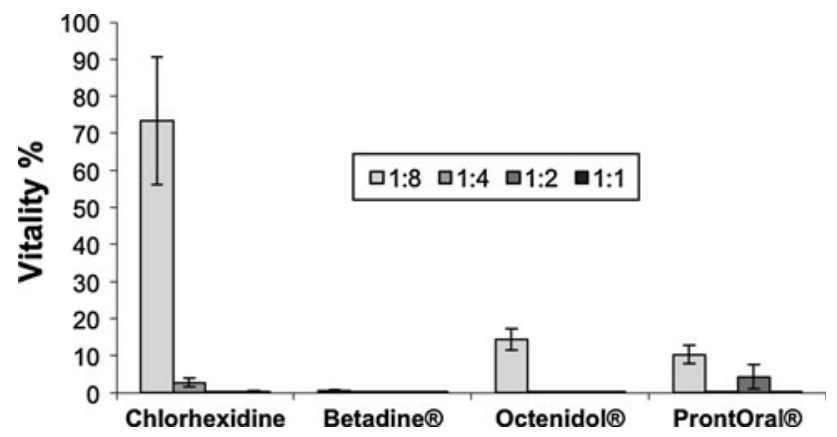

Fig. 3 Vitality percentage of disinfectant-treated samples compared to the untreated control measured by isothermal microcalorimetry. Mean values with standard deviations are given $(n=3)$
$14.49 \% \pm 2.87$ by $1: 8$ of Octenidol $^{\circledR}, 10.21 \% \pm 2.49$ by $1: 8$ of ProntOral ${ }^{\circledR}$ and $4.28 \% \pm 3.28$ by $1: 2$ of ProntOral $^{\circledR}$.

The mean maximum growth rate in control samples was $1.14 \pm 0.21 \mathrm{~h}^{-1}$ and for the treated samples grouped all together $1.14 \pm 0.78 \mathrm{~h}^{-1}$. The average accumulated heat produced by control samples in $48 \mathrm{~h}$ was $6.54 \pm 0.13 \mathrm{~J}$ and this of the treated samples grouped all together $5.74 \pm 0.25 \mathrm{~J}$. No significant difference was detected between the untreated control sample and any of the treated samples for either of these parameters $(P>0.05)$, which indicates that equivalent numbers of bacteria were created and disinfectants delayed growth but were not able to eliminate it.

\section{Discussion}

In the present study three methods were used to analyse the vitality rates of adherent bacteria after direct exposure to four disinfectants in order to compare the methods and define their optimal usage. The techniques applied were: live/dead staining and two methods based on the cultivability of the cells-the conventional culture method to count survived bacteria as colonies on a solid media, and IMC - using the cumulative heat production versus time curves of the samples to quantify the amount of the cells in the liquid media. To achieve comparable data, the results revealed by each method were converted into vitality percentages \pm SD.

It is well-known that bacterial response to chemical and environmental stress results in activating low-metabolism survival mechanisms. A common related response to such stress on bacterial cells is an inability to develop into colonies on routine culture media, even though the cells may remain viable for long periods of time. As cells in the viable but non-cultivable (VBNC) state are no longer culturable, alternate nonculture methods must be used to demonstrate their vitality. A commonly used method is staining (e.g. the Live/Dead BacLight ${ }^{\mathrm{T}}{ }^{\mathrm{M}}$ assay) designed to demonstrate the percentage of cell exhibiting cytoplasmic membrane integrity (and presumed viability), through direct microscopic examination [4, 10]. Despite their typically low levels of metabolic activity, these bacteria are again culturable upon resuscitation. The VBNC cells are one of the major hindrances each treatment protocol might encounter. Under suitable conditions the VBNC cells are able to overcome the stress and re-grow to the same density the cell population had before the applied treatment. Therefore, monitoring the behaviour of the disinfectant-treated bacteria in their favourable environment leads to a better insight of what is happening to the VBNC cells. 
All disinfectants showed dose-dependent effects throughout the study with a minor and not significant exception in the Octenidol ${ }^{\circledR}$ group in results of the live/dead staining. This can be explained by the high efficacy of the disinfectant reducing the percentage of vital cells to less than $5 \%$. The vitality percentages measured by live/dead staining were considerably higher than those measured by either the conventional culture methods or IMC, especially for chlorhexidine and Betadine ${ }^{\circledR}$. On one hand, a possible high population of VBNC cells (with intact membranes) may lead to higher viability percentages for live/dead staining than the methods based on culturing [15]. On the other hand, lower viability percentages for the culture methods could be due to killing of more cells through the necessary handling procedures. However, bacteriostatic effects of disinfectants remain beyond the sensitivity of the live/ dead method. In case of Betadine ${ }^{\circledR}$, which is based on an iodide complex, the interference with the propidium iodide in the staining step should be considered as a confounding factor that might reduce the percentage of dead cells correctly stained. Thus, for the first time ever the present results indicate that live/dead staining may have severe limitations for in vitro susceptibility testing due to possible interactions with iodine-based antimicrobial agents.

The CFU/ml determined in untreated control samples showed no significant difference between the conventional culture method and microcalorimetry, thereby making the discrepancy in the results between the methods even more obvious. An immense difference in results was observed in the samples treated with chlorhexidine, where a dosedependent effect was detected by conventional culture and by live/dead staining, but IMC only detected a significant amount of bacteria in the sample treated with lowest concentration of the disinfectant.

The IMC experiments were run at $37^{\circ} \mathrm{C}$ for $48 \mathrm{~h}$ in a suitable media for $S$. sanguinis to grow. Such a setup enables one to monitor also the long-term bactericidal effects of the disinfectants because any unkilled cells need considerable time to become metabolically active again and replicate sufficiently to result in a detectable heat flow. Over $48 \mathrm{~h}$ there was no difference in total heat between treated and untreated samples $(P>0.05)$, indicating equivalent numbers of bacteria were created and disinfectants delayed growth but did not eliminate it. The sample treated with a 1:8 dilution of chlorhexidine was the only one which showed a high rate of vitality by microcalorimetry at the beginning of the experiment.

In this study model, $48 \mathrm{~h}$ was enough to observe by IMC the resuscitation and growth of the disinfectant-treated bacteria to the same level as the untreated control, despite the significant differences in the starting disinfectant concentrations.

\section{Conclusions}

Live/dead staining is intended to detect bacterial cell death based on destruction of the cell membrane. The higher percent viable cells-right after treatment-found by this method compared to the culture methods indicates that the higher percentage of viable cells determined by live/dead staining also includes VBNC cells.

The conventional culture method used was not able to detect VBNC cells and thereby underestimates the count of bacteria able to re-colonize the surface. Although IMC is based on culturing, too, it allows unique evaluation of relative disinfectant effects by quantifying differences in time delay of regrowth of remaining vital cells-i.e. cells that would be classified as VBNC cells by conventional culture. As a completely "non-invasive" monitoring method with high sensitivity, reproducibility and simplicity, IMC is a more appealing method of choice than conventional culture method to observe the efficacy - and dynamics—of disinfectants in vitro.

\section{References}

1. Auschill TM, Hein N, Hellwig E, Follo M, Sculean A, Arweiler NB. Effect of two antimicrobial agents on early in situ biofilm formation. J Clin Periodontol. 2005;32:147-52.

2. Cousido MC, Tomás Carmona I, García-Caballero L, Limeres J, Alvarez M, Diz P. In vivo substantivity of $0.12 \%$ and $0.2 \%$ chlorhexidine mouthrinses on salivary bacteria. Clin Oral Investig. 2010;14:397-402.

3. Decker EM, Maier G, Axmann D, Brecx M, von Ohle C. Effect of xylitol/chlorhexidine versus xylitol or chlorhexidine as single rinses on initial biofilm formation of cariogenic streptococci. Quintessence Int. 2008;39:17-22.

4. Hope CK, Wilson M. Analysis of the effects of chlorhexidine on oral biofilm vitality and structure based on viability profiling and an indicator of membrane integrity. Antimicrob Agents Chemother. 2004;48:1461-8.

5. McBain AJ, Bartolo RG, Catrenich CE, Charbonneau D, Ledder RG, Gilbert P. Effects of a chlorhexidine gluconate-containing mouthwash on the vitality and antimicrobial susceptibility of in vitro oral bacterial ecosystems. Appl Environ Microbiol. 2003;69:4770-6.

6. Pan PC, Harper S, Ricci-Nittel D, Lux R, Shi W. In vitro evidence for efficacy of antimicrobial mouthrinses. J Dent. 2010;38(Suppl 1):S16-20.

7. Rohrer N, Widmer AF, Waltimo T, Kulik EM, Weiger R, Filipuzzi-Jenny E, et al. Antimicrobial efficacy of 3 oral antiseptics containing octenidine, polyhexamethylene biguanide, or Citroxx: can chlorhexidine be replaced? Infect Control Hosp Epidemiol. 2010;31:733-9.

8. Tandjung L, Waltimo T, Hauser I, Heide P, Decker EM, Weiger R. Octenidine in root canal and dentine disinfection ex vivo. Int Endod J. 2007;40:845-51.

9. Weiger R, de Lucena H, Decker E, Löst C. Vitality status of microorganisms in infected human root dentine. Int Endod $\mathrm{J}$. 2002;35:116-71.

10. Decker E-M. The ability of direct fluorescence-based, two-colour assays to detect different physiological states of oral streptococci. Lett Appl Microbiol. 2001;33:188-92. 
11. Bandara HM, Yau JY, Watt RM, Jin LJ, Samaranayake LP. Escherichia coli and its lipopolysaccharide modulate in vitro Candida biofilm formation. J Med Microbiol. 2009;58:1623-31.

12. Kim J, Pitts B, Stewart PS, Camper A, Yoon J. Comparison of the antimicrobial effects of chlorine, silver ion, and tobramycin on biofilm. Antimicrob Agents Chemother. 2008;52:1446-53.

13. Shen Y, Stojicic S, Haapasalo M. Bacterial viability in starved and revitalized biofilms: comparison of viability staining and direct culture. J Endod. 2010;36:1820-3.

14. Xu H-S, Roberts N, Singleton FL, Attwell RW, Grimes DJ, Colwell RR. Survival and viability of nonculturable Escherichia coli and Vibrio cholerae in the estuarine and marine environment. Microb Ecol. 1982;8:313-23.

15. Oliver JD. Recent findings on the viable but nonculturable state in pathogenic bacteria. FEMS Microbiol Rev. 2010;34:415-25.

16. Higuera-Guisset J, Rodriguez-Viejo J, Chacon M, Munoz FJ, Vigues N, Mas J. Calorimetry of microbial growth using a thermopile based microreactor. Thermochim Acta. 2005;427:187-91.

17. Wadsö I. Isothermal microcalorimetry in applied biology. Thermochim Acta. 2002;394:305-11.

18. Braissant O, Wirz D, Goepfert B, Daniels AU. Use of isothermal microcalorimetry to monitor microbial activities. FEMS Microbiol Lett. 2010;303:1-8.

19. Braissant O, Wirz D, Goepfert B, Daniels AU. Biomedical use of isothermal microcalorimeters. Sensors. 2010;10:9369-83.

20. Bäckmann P, Wadsö I. Cell growth experiments using a microcalorimetric vessel equipped with oxygen and $\mathrm{pH}$ electrodes. J Biochem Biophys Methods. 1991;23:283-93.

21. Bunker JC, James AM. Microcalorimetric studies on the effects of media and environmental conditions on the growth of bacteria. Microbios. 1986;47:177-88.

22. Ruming Z, Yi L, Zhixiong X, Ping S, Songsheng Q. A microcalorimetric method for studying the biological effects of La3+ on Escherichia coli. J Biochem Biophys Methods. 2000;46:1-9.
23. Sand W, von Rège H. Evaluation and quantification of bacterial attachment, microbial activity, and biocide efficacy by microcalorimetry. Methods Enzymol. 1999;310:361-74.

24. Postollec F, Norde W, van der Mei HC, Busscher HJ. Enthalpy of interaction between coaggregating and non-coaggregating oral bacterial pairs-a microcalorimetric study. J Microbiol Methods. 2003;55:241-7.

25. Boling EA, Blanchard GC, Russell WJ. Bacterial identification by microcalorimetry. Nature. 1973;241:472-3.

26. Lopez D, Vinas M, Loren JG, Bermudez J. Analysis of microcalorimetric curves for bacterial identification. Can J Microbiol. 1987;33:6-11.

27. Monk $P$, Wadsö I. The use of microcalorimetry for bacterial classification. J Appl Bacteriol. 1975;38:71-4.

28. Vine GJ, Bishop AH. The analysis of microorganisms by microcalorimetry in the pharmaceutical industry. Curr Pharm Biotechnol. 2005;6:223-38.

29. Hauser-Gerspach I, de Freitas PS, Dan Daniels AU, Meyer J. Adhesion of Streptococcus sanguinis to glass surfaces measured by isothermal microcalorimetry (IMC). J Biomed Mater Res. 2008;85:42-9.

30. Gompertz B. On the nature of the function expressive of the law of human mortality, and on a new mode of determining the value of life contingencies. Philos Trans R Soc London. 1825;115:513-85.

31. Zwietering MH, Jongenburger I, Rombouts FM, van't Riet K. Modeling of the bacterial growth curve. Appl Environ Microbiol. 1990;56:1875-81.

32. Cho SB, Nakanishi K, Soga N, Ohtsuki C, Nakamura T, Kitsugi $\mathrm{T}$, et al. Defence of apatite formation on silica gel on its structure: Effect of heat treatment. J Am Ceram Soc. 1995;78:1769-74.

33. Hauser-Gerspach I, Kulik EM, Weiger R, Decker EM, von Ohle C, Meyer J. Adhesion of Streptococcus sanguinis to dental implant and restorative materials in vitro. Dental Mater J. 2007;26:361-6. 